\title{
HOMER AND THE CULT OF THE DEAD IN HELLADIC TIMES
}

This paper discusses the Homeric bothros (Odyssey X $517 \mathrm{ff}$.) as a possible source of information for the ritual and function of various bothroi (grave pits) which are considered to be an important archaeological source. It seems that the bothroi were, by their nature, best suited to a cult of the dead and served as altars. The paper also discusses the possible reasons for the existence of the cult and argues against the view that fear of the dead motivated the cult in Helladic times.

The study of the archaeological evidence for the cult of the dead first began with the pioneer work of Schliemann '. Nilsson pursued it further ${ }^{2}$, and he was followed by Mylonas and others ${ }^{3}$. But the undisputed evidence was difficult to find. More recent material has still not yielded positive results ${ }^{4}$, and yet there is something, perhaps a great deal, we can learn about the cult if we adopt a new approach with Homer to guide us.

It was correctly assumed from the start that a cult of the dead required some sort of an altar. The problem is that students of the cult failed to say what would be a suitable altar. As it stands the altars found are identical with those of ordinary divine cult. But it has yet to be shown that the same type of altar was used in both cults, and I think that we have been looking in the wrong direction for supporting evidence of the cult. We should be closer to the truth if we concentrate upon altars resembling those of chthonic gods which differ considerably from the altars of the sky gods: they are underground structures in the

\footnotetext{
' H. Schliemann, Mycenae, N. York 1885 (Repr. 1967), p. 212 ff., and C. Schuchhurdt, Schliemanns Ausgrabungen, Leipzig 1890, p. 129 ff.

${ }^{2}$ M. P. Nilsson, The Minoan-Mycenaean Roligion and its Survival in Greek Roligion, 2nd ed., Lund 1950, p. $426 \mathrm{ff}$.

${ }^{3}$ G. E. Mylonas, Mycenae and the Mycenaean Age, Princeton 1966, p. $176 \mathrm{ff}$.

4 Cf. n. 37 below.
} 
form of a pit (usually circular), while the others rise above the ground and are usually rectangular ${ }^{5}$. Both the dead and the chthonic deities dwelled, in the general belief of the Greek people, underground. In Homer the dead always go down to Hades ${ }^{6}$, and the belief was certainly much older than the Greek epic. So it would be quite natural for people to imagine that any offerings to the dead would best be directed to them through an altar appropriate to underground dwellers.

Schliemann unearthed a well-like structure over Grave IV of the Mycenaean Circle which he called «a primitive altar for funeral rites" and concluded from its location that wit had been erected in honour of those whose mortal remains reposed therein"?. For Nilsson it was "a typical altar of the cult of the dead" ". Mylonas shared this view but later he changed his mind arguing that the altar was too deep in the ground to have been used for cult practices when the Grave Circle was erected $^{9}$. There can be no doubt that this rough but impressive structure rising $4 \mathrm{ft}$. above the ground had some ritualistic significance ${ }^{10}$. But the question is whether this "altar" served a cult of the dead or a divine cult.

There is another altar painted on the sarcophagus of Hagia Triada ", and some inferences may be drawn from the context about its significance. The religious painting itself was viewed at first as indicating strongly that a cult of the dead existed in Minoan Crete ${ }^{12}$, but

\footnotetext{
${ }^{3}$ On the subject in general see P. Stengel, Die griechischen Kultusaltertümer, 3rd ed., München 1920 (Handbuch der klassischen Allertumswissenschaft, V), p. 11 ff., esp. pp. 13 and 15.

- Cf. for example Il. VI 19

${ }^{7}$ Op. cit., p. 213.

Op. cit., p. 608.

'Op. cit., pp. 94 and 178, and his paper *The Cult of the Dead in Helladic Times* in Studies Presented to D. M. Robinson (ed. G. E. Mylonas), St. Louis 1951, p. 96. M. Andronikos, Totenkult. Archaeologia Homerica III, Göttingen 1968, p. 128, suggests that the altar was in use before it was covered.

${ }^{10} \mathrm{Cf}$. also C. G. Yavis, Greek Altars, St. Louis 1949, p. 34 . It may be noted in this context that four stone enclosures were found at Asine among the graves, and A. Persson, Asine. Results of the Swedish Excatations 1922-1930, p. 347, thought they were grave altars. «direct predecessors of the tomb-altar found by Schliemann*. Mylonas, Studies, p. 77, argues against this view.

"It may be noted that altars are regularly painted in funerary scenes (cf. E. T. Vermeule, «Painted Mycenaean Larnakes*, JHS 85, 1965, p. 145).

12 Cf. Nilsson, op. cit., p. 438 with reference to Paribeni, MonAnt 19, 1908, who first described it, and his summary (p. $430 \mathrm{ff}$.) of modern irreconcilable views. For a recent discussion of the religious context cf. J. A. Sakellarakis, *Das Kuppelgrab A von Archanes und das kretisch-mykenische Tieropferritual», $P Z 45,2,1970$, p. $178 \mathrm{ff}$.
} 
criticism pruned some misconceptions ${ }^{13}$, and it is now doubtful whether the scene of sacrifice can be related solely to that cult ${ }^{14}$. Symbols of divine cult such as double axes and horns of consecration suggest that the depicted ceremony may be intended for some Minoan deity or deities on the occasion of the man's burial, and the bird at the scene of sacrifice supplies proof of a divine epiphany ${ }^{15}$ of some earth or sky deity ${ }^{16}$. Nilsson quotes with approval Paribeni's view that the Minoans invoked their gods at the burial to bless the departed. If the sacrifice is in fact intended for the gods the altar belongs to divine cult. If the man is deified ${ }^{17}$ we do not know exactly what deification involves in Minoan Crete in terms of rites, and in any case not all dead were deified.

With due allowance made for possible variations in the funeral rites between Minoans and Mycenaeans, and also for possible artistic conventions we can say that Schliemann's altar conforms to the type exemplified by the sarcophagus of Hagia Triada: both rise above the ground ${ }^{18}$. We should like to think that whatever sacrifice was placed upon them was meant for some deity or deities of the upper world.

It is important to establish the type of altar suitable for the cult if we are to make headway in the search for convincing archaeological evidence $^{19}$. In 1905 Soteriades excavated a tomb of the Middle Helladic Period near Drachmani in Phokis ${ }^{20}$ and he discovered a pit located

\footnotetext{
${ }^{13}$ Mylonas, Mycenae, p. $176 \mathrm{ff}$.

14 The bull sacrifice of Archanes (Sakellarakis, p. $187 \mathrm{ff}$.) seems to shed light on some other aspects of the problem.

15 On bird epiphany in Minoan religion see F. Matz, Göttererscheinung und Kulebild im minoischen Kreta, Wiesbaden 1958, passim, and E. F. Willets, Cretan Cults and Festivals, London 1962, p. 312.

${ }^{16}$ It would be surprising if the perched bird represented a deity of the nether world, even assuming that the mother goddess extended her power to that world (cf. Picand, Les Religions Prehelléniques (Crète et Mycènes), Paris 1948, p. 754.

${ }^{17} \mathrm{Cf}$. Nilsson, op. cit., p. 439 f. and others. Against the view of deification Mylonas, Studies, p. 102.

18 The Mycenaean structure is hollow but the reason is not known. A. J. B. Wace, Chamber Tombs at Mycenae, Oxford 1952, p. 61, suggests, "probably for the pouring of libations to the dead below".

10 The niches on the sides of the dromos and in the chambers proved to have a function different from the one assumed by the supporters of the cult (cf. Mylonas, Mycenae, p. $179 \mathrm{ff}$.), and the religious utensils found in the tombs and graves (cf. V. R. d'A. Desborough, The Last Mycenaeans and their Successors, Oxford 1964, p. 40) yield no more satisfactory results (cf. B. C. Dietrich, The Origins of Greek Religion, Berlin-N. York 1974, p. 163).

${ }^{20}$ Ephem. Archaeol. 1908, p. 94 ff.
} 
nearby which contained ashes and charred matter. This find is important but it was not put in the right perspective, for the pit was compared to Schliemann's altar ${ }^{21}$ which is, as we have seen above, a different structure altogether: while it rises above the ground the pit is a underground structure 22 . In 1913 a large hollow was revealed by accident in the center of the Grave Circle leading to Graves I and IV; ashes were found inside and also traces of an hearth ${ }^{23}$. This is unlike the Drachmani pit; cult practices took place in this area but their specific nature is not known ${ }^{24}$.

In more recent times a number of pits have been found in Mycenaean sites ${ }^{25}$. That there was a religious function ascribed to them from the beginning is clearly suggested by the fact that they are located near graves or directly over them ${ }^{26}$. It would seem then that we are on safer ground if we concentrate on grave pits in our endeavor to find archaeological evidence for the cult of the dead. The problem is to specify the function of pits dating from Helladic times. But there is a passage in Homer which gives us some insight into the matter; in fact it. is the only illuminating context we have ${ }^{27}$.

In Odyssey X $517 \mathrm{ff}$. Circe advises Odysseus to make an offering to the dead before communicating with them, and to this end he must dig

\footnotetext{
${ }^{21}$ Cf. C. W. Blegen-A. J. B. Wace, «Middle Helladic Tombs", SO 9, 1930, p. 34.

${ }^{22}$ Mylonas too seems not to draw a clear line between them (cf. Studies, p. 79 f.).

${ }^{23}$ Cf. A. Keramopoullos, Ephem. Archaeol. 1918, p. 52 ff., and Mylonas, Studies, p. 96.

${ }^{24}$ For Nilsson, op. cit., p. 609, this area is *enigmaticals, while Keramopoullos thinks it has to do with the cult of the dead.

${ }^{25}$ For a detailed description of them see J. Deshayes, *Argos, les Fouilles de la Deiras*, Études Peloponnesiennes 5, 1966, p. 15 ff. and J. Servais, «Le secteur mycénien sur le haut du Vélatouri-, Thorikos 1963, Brussels 1968, p. 27 ff., esp. 28 ff.

26 So for example "La tombe 23 était situce au centre méme du bothros $n .^{\circ} 1$ " (Deshayes, p. 73) and «Il est probable que la tombe XXVI avait eté creusce sous un bothros mesohelladique*. Cf. further pp. 93 and 103, and also Servais who thinks that the bothros was "pour recevoir les libations offertes au mort", p 38). Mylonas, «Excavations at Haghios Kosmas*, AJA 38, 1934, p. 271, speaks of a esacrificial bothros* found near grave 11 (cf. also his Studies, p. 67). For *house-pits* see R. W. Hutchinson's discussion, *Bothroi*, JHS 55, 1935, p. 1 ff.

${ }^{27}$ It has not been quoted in discussions dealing with a cult of the dead, and those who noticed it completely overkoked relevant archaeological material and its relation to it (cf. A. Schnaufer. Frühgriechischer Totenglaube, Untersuchungen zum Totenglauben der mykenischen und homerischen Zeit, Hildesheim 1970 (Spudasmata 20), p. 88 f. Mylonas, noting only vv. $521 \mathrm{ff}$., states very firmly, *Homeric and Mycenaean Burial Customs*, AJA 52, 1948, p. 78. - There is no evidence in the Homeric poems proving the existence of a cult of the dead. But it all depends upon what kind of evidence we are looking for.
} 
a pit in which to pour a mixture of milk and honey, wine and water, adding barley ${ }^{2 \mathrm{x}}$ :

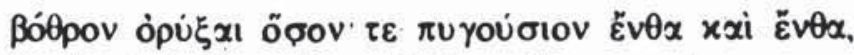

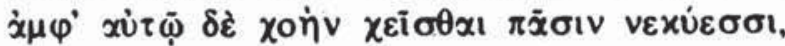

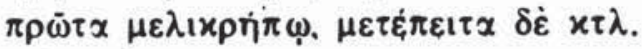

Note first that the meal offering is common in chthonic cult ${ }^{29}$. Circe also advises Odysseus to sacrifice a black sheep ( $526 \mathrm{ff}$.) characteristic of the same cult ${ }^{30}$; the blood is to tlow into the bothros (XI 36) ${ }^{31}$. The sacrifice is a holocaust for the nether gods $\left(531 \mathrm{ff}\right.$.) ${ }^{32}$. The location of the burnt offering is not specified but it should be near the bothros.

We are further told that additional offerings are due to the dead: upon arriving home Odysseus should offer a barren heifer and gifts $\left(521 \mathrm{ff}^{3}\right)^{33}$. The ritual is to take place in the palace (523):

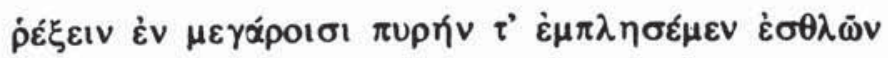

Such a sacrifice requires an altar, presumably a bothros ${ }^{34}$.

Before we discuss the underlying concepts of the ritual described in the above passage let us first take a closer look at the. Homeric bothros. Surprisingly enough it is very small and hardly 15 inch. in diame-

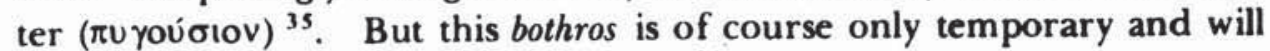
do for Odysseus' purpose. Permanent ${ }^{36}$ bothroi discovered in the recent past are well structured and vary in size ${ }^{37}$. The fact that the man used

${ }^{2 x} \mathrm{Cf}$. also $\mathrm{Od}$. XI $25 \mathrm{ff}$. where Odysseus repeats Circe's instruction.

${ }^{24}$ Cf. H. V. Herrmann, *Omphalos*, Orbis antiquus 13, Münster 1959, p. 81. According to Stengel, op. cit., p. 151, the cult of the dead does not differ from that of the chthonic deities.

${ }^{30}$ Stengel, p. 152.

"On the etymology cf. O. Szemerényi, Glotta 38, 1960, p. $215 \mathrm{f}$. In this context see also G. P. Oeconomos, De profusionum receplaculis sepulchralibus, Athens 1921, p. 11.

${ }^{32}$ Whether it has a meaning for the dead as well is hard to say. Yet cf. Schnaufer, p. 89.

${ }^{33}$ Rohde, Psyche, p. 58, sees here "Rudimente alten Seelenkultes", for according to prevailing concepts in Homer the dead cannot have the "Genuss des Opfers".

${ }^{34}$ A walled pit was found in the court of the megaron of Tiryns. Schuchhardt, op. cit., p. $129 \mathrm{f}$. describes it as *eine Opfergrube oder besser einen altar in Gestalt einer Opfergrube* (p. 190). In this context see also Yavis, op. cit., p. 36, and Mylonas, Mycenae, p. 162 f., who contends that the find is not Mycenaean.

${ }^{35}$ On the term derived from $\pi u \gamma \omega \dot{v}$ (*the distance from the elbow to the first joint of the fingers*, Lidd.-Scott, Lex., p. 1550) see H. Frisk, Griech. etym. Wörterb. I, p. 619.

${ }^{36}$ Paus. VI 24, 2 and V 13, 8, comments on the structure of altars in general; it should Ix obvious of course that some altars were better built than others.

${ }^{37}$ Cf. Deshayes, op. cit., p. 16 f., Servais, op. cit., p. 38, and Mylonas, Studies, p. 67. The 
his sword (äop ö६ú, XI 24) to dig proves that this bothros is rather shallow. But we are dealing here with an emergency away from home.

The Homeric context seems to illustrate the general function of the bothros: this type of altar is ideally suited for offering non-solid food, including animal blood ${ }^{38}$, both to the dead and to the gods of the underworld. But what about the animal sacrifice itself. Odysseus performs it primarily because he is crossing the realm of the nether gods. Was it customary to sacrifice to the same gods at a person's burial which might be felt to be some sort of crossing into that realm? ${ }^{39}$ In the same context no altar is erected upon which to burn the slaughtered animals ${ }^{40}$, which is consistent with the view stated above that altars rising above the ground are not suitable for gods who in the general belief of their worshippers dwell underground. Animal ash was found in bothroi ${ }^{41}$. We can safely assume that as a pit-altar the bothros was also used for animal sacrifices. The Homeric context, we have seen, makes it clear that the dead too receive such sacrifices.

About the ritual itself Rohde says that it reflects older religious concepts, for it assumes that the dead regain consciousness after they are given food, which conflicts with the Homeric view of the powerless and done for dead; the food offering presupposes the belief in the "living corpse" which only existed in pre-Homeric times prior to cremation; so we are dealing with fossilized religious elements ${ }^{42}$. This may

\footnotetext{
bothros discovered more recently in the Minoan cementery of Archanes measures $1,20 \mathrm{~m}$. in diameter and $2,00 \mathrm{~m}$. in depth. On the date and other topographical details of this

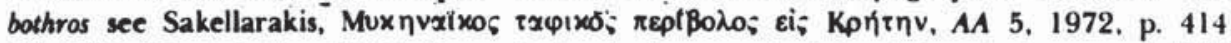
ff. With Dr. Sakellarakis' kind permission I photographed the bothros in August of 1978 (cf. figs. $a$ and b). For the financial assistance for my trip to Archanes I thank the Humanities Research Council of Canada.

${ }^{38}$ Cf. Stengel, p. 148. Sakellarakis, op. cit.. P. 414, thinks that the Archanes bothros served this purpose and he finds more evidence in the cemetery for the practice of a cult of the dead.

30 Animal sacrifices took place near graves; bones litter Mycenaean and Minoan burial grounds (Mylonas, Studies, p. 94). But were those sacrifices meant for the gods or for the dead or for both?

40 Yet cf. for instance Apoll. Rhod. I 403, 966, 1123, II 695, where the argonauts collect rocks from the river banks to build altars in the absence of permanent structures: it is essential that they do so since they want to sacrifice to sky gods. Paus, IX 3, 4 reports that temporary altars are erected on certain emergencies when nothing else is available.

${ }^{41}$ Cf. Bulle, Orchomenos I, Abh. Bayer. Akad. Philos.-Philol. Kl. 24, 2, 1907, p. $30 \mathrm{ff}$.

${ }^{42} \mathrm{Op}$. cil., p. 57, *Auch hier sehen wir versteinerte sinnlos gewordene Rudimente eines einstmals im Glauben voll begründenten Brauches vor uns, vom Dichter um dichterischer Zwecke willen hervorgezogen und nicht nach ihrem ursprünglichen Sinne verwendet*.
} 


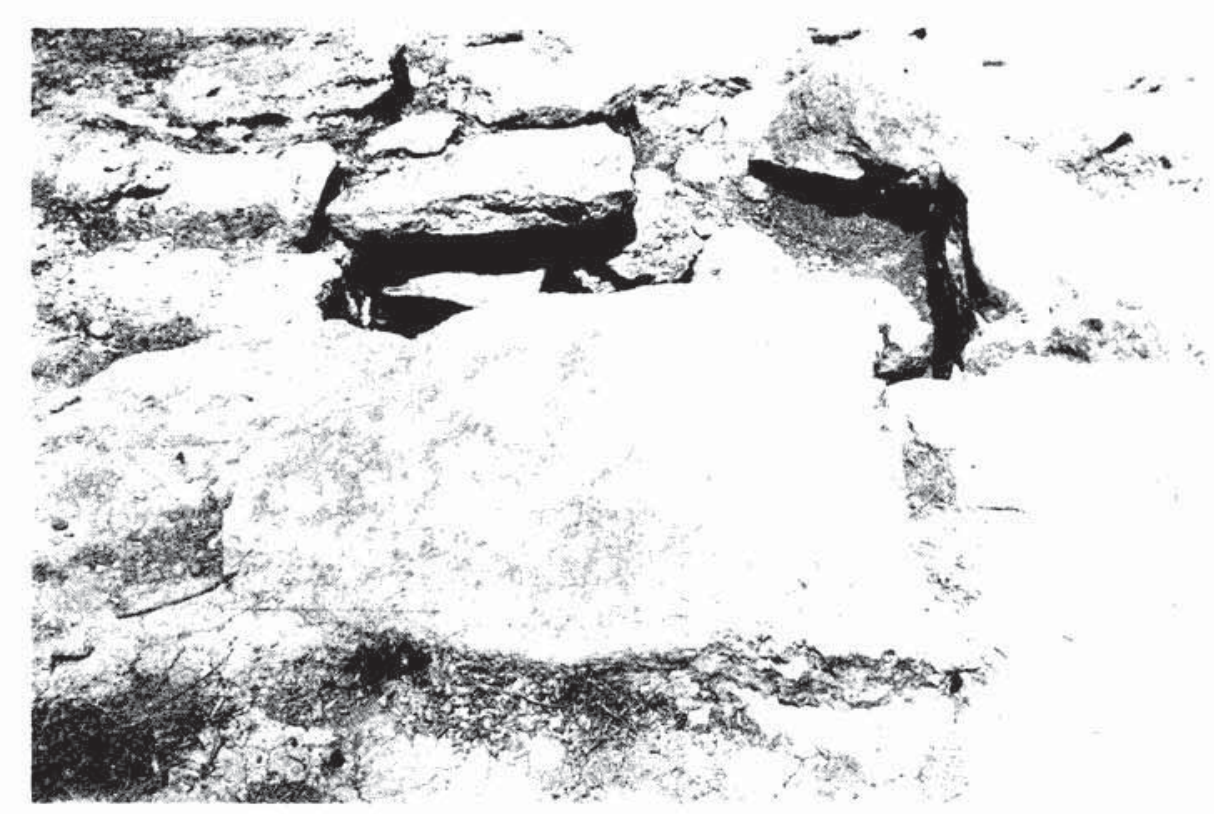

The bothros of Archanes

IFig. a, surface

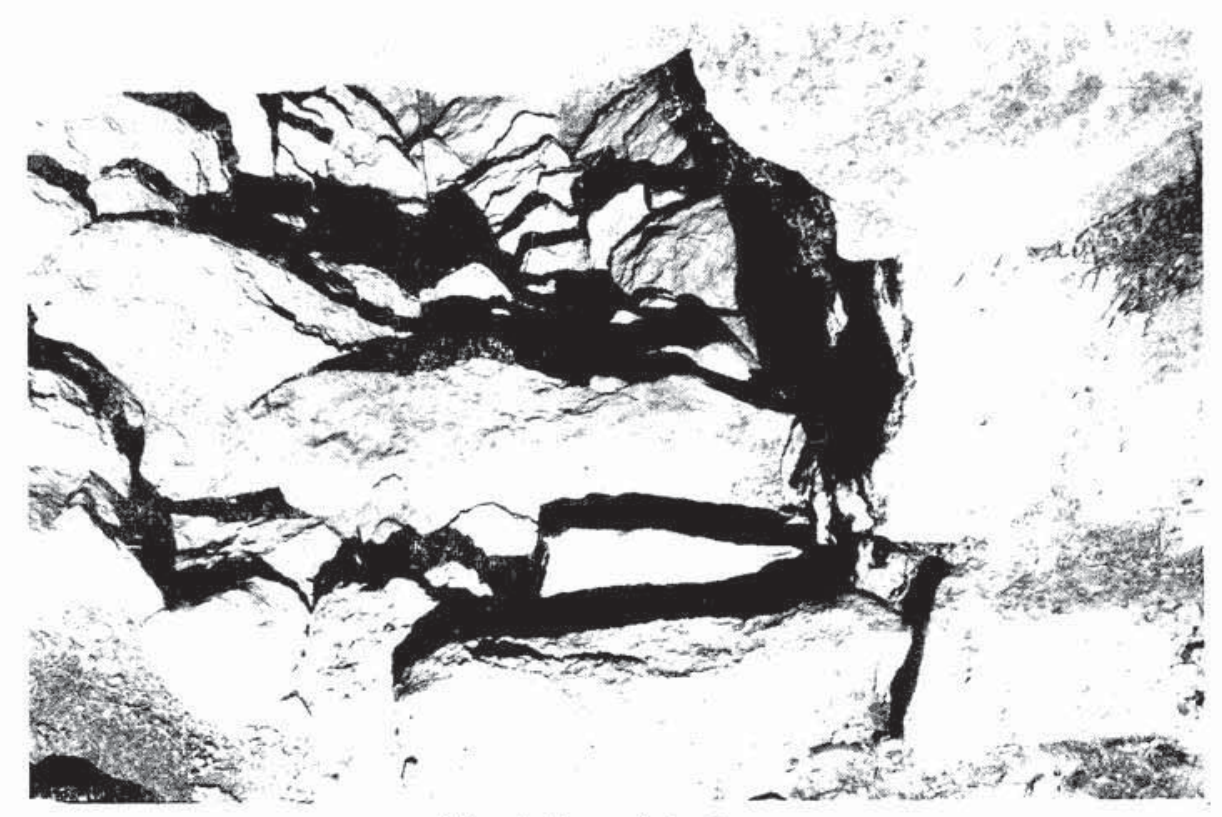

The bothros of Archanes

Fig. b, interior 
be so; what appears certain is the poet's knowledge of the ritual; he has not invented it or the bothros upon which it centers ${ }^{43}$.

The archaeological fact that bothroi are located near graves and tombs $^{44}$ sheds more light on the meaning of the ritual: graves and tombs house the dead, and the ritual can only concern them; in all of its aspects, including sacrifices to the nether gods. This is where the dead would best be imagined to come. In Homer the «spirits" gather at the bothros (Od. X $529 \mathrm{f}$. and $535 \mathrm{ff}$.), i. e. in the place where the food is available for them. In the poetic setting of the story Odysseus must communicate with the dead, especially with the prophet Tiresias to learn his future, and for the contact to be established the dead should be given food and the blood of the slain animals ${ }^{45}$. Now would ordinary worshippers perform the same ritual in order to communicate with the dead or would they perform it for some other reason? Furthermore, could such a ritual be essential to a cult of the dead or even necessitate it? Which are the reason, if any, for the existence of the cult? These questions we shall presently consider.

Mention was made above of the $*$ living corpse ${ }^{46}$. We are told that there was fear of it before cremation liberated the Greek from that fear ${ }^{47}$ : fire destroys the body, and so there is no "living corpse" left behind to vex the living ${ }^{48}$. As long as there is a "living corpse" there is, we are told, a need to placate it and to secure its blessings by means of offerings, and such a need would seem then to be at the root of a cult of the dead.

${ }^{43}$ It is hardly necessary to remind the reader that Homer's religion is rooted in an historical world. Cf. my study Nature and Background of Major Concepts of Divine Power in Homer, Amsterdam 1977, passim.

${ }^{44}$ Cf. $n .25$ above and $n .80$ below.

${ }^{45}$ Circe is very explicit on this point: Odysseus should first let Tiresias drink and then other spirits (Od. X 536 f., XI 48 f.).

${ }^{46}$ On the concept Nilsson, Gesch. d. griech. Rel. I, p. 40. Cf. also Schnaufer (op. cit., p. 69 f.).

${ }^{47}$ Cf. Rohde, op. cit., p. 32, who quotes in the same context an Icelandic saga and stoires about «vampires* (p. 32, n. 1). Following Rohde Schnaufer speaks of a *gespenstiges Wirken - of the dead among the living in Mycenaean times (p. 178). For Mylonas, Mycenae, p. $134 \mathrm{f}$., people ceased to fear the dead when the body was completely decomposed.

4n Schnaufer, op. cit., p. 69 f., with reference to Nilsson. 
It may be true that there exists a «primitive Vorstellung von einem Totenwesen, das wie der einst Lebende weiterexistiert" ${ }^{49}$, but to what extent can pre-Homeric religious concepts be called "primitive»? ${ }^{30}$ Did the Greek people really fear their dead? Do burials in jars interred beneath the house floor ${ }^{51}$ not suggest that people regarded their dead «with affection rather than with terror* as Farnell put it? ${ }^{32}$ On the painted Mycenaean larnakes we encounter human grief and tearful faces ${ }^{53}$ but no trace of fear. Creatures like the Griffin or Sphinx on Cretan larnakes ${ }^{54}$ hardly symbolize this kind of fear, if any ${ }^{55}$; they are art motifs of Eastern origin ${ }^{56}$. The recurrent motif of mourning is human enough, and its portrayal indicates no fear or anxiety whatsoever.

There is an interesting detail of the funerary scene: the dead is shown upright, and he is «clearly armless and in his shroud to emphasize that he is no longer active in life ${ }^{57}$. This portrayal most certainly suggests helplessness (before cremation) and it conflicts with Rohde's view of the powerful *living corpse* ${ }^{38}$. The absence of a weapon or hostile gesture is remarkable and self-explanatory in its context ${ }^{59}$. But even the view that the dead walk could be challenged -at least as far as

49 Schnaufer, lor, rit.

so In his learned work The Fear of the Dead in Primitive Religion, N. York 1966 (Repr.), p. 5, Sir J. G. Frazer qualifies the term *primitive* in a way that would be clearly inapplicable to the ruling class of the Minoan and Mycenaean societies.

si Cf. H. J. Rose, Primitive Culture in Greece, London 1925, p. 128, and E. A. Branopou-

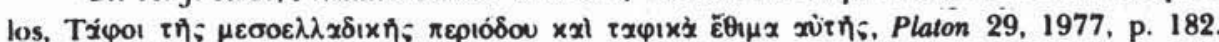

"2 L. R. Farnell, Greek Hero Cults and Ideas of Immortality, Oxford 1921, p. 4. Similarly Frazer, op. cit., p. 18.

"s C. Vermeule, op. cit., p. 139. There are scenes of the * mourning of the dead in the house or at the tomb" and "gestures of mourning" (p. 141). There is also the theme of the "picture of the mourner" and its variations (p. 142). In this context see also S. E. lakobidis, *A Mycenaean Mourning Custom*, AJA 70, 1966, p. 43 ff., esp. 46.

"Vermeule, p. 140.

" For monster symbolism on Protocorinthian pottery (c. 700 B. C.) cf. C. G. Starr, The Origins of Greek Cinilization, London 1962. p. $280 \mathrm{ff}$.

so (f. Webster, From Mycenae to Homer, pp. 32, 39 and H. Frankfort, *Notes on the Cretan Griffin*, BSA 37, 1936-1937, p. 106 ff.

"Vermeule, p. 144. I cannot share Vermeule's view that the dead person is pictured standing in order to be seen. Who did not know who was in the sarcophagus? Besides the dead could still be seen if pictured lying down.

sm Schnaufer (p. 129 f.) finds the old belief in the Homeric hero's desire to strip the opponent's body of its weapons: once the body is thus rendered harmless it cannot, as a "living corpse", be as dangerous. Schnaufer seems to be aware that there are other, more convincing. explanations of the stripping of the enemy's body.

sy Already in the late Bronre Age the dead appear as winged apparitions on larnakes. 
some areas of the Greek world are concerned. There is a boat on the funerary scene of the sarcophagus of Hagia Triada which is also found in Aegean graves ${ }^{60}$. If it symbolizes departure or journey ${ }^{61}$ there remains no *living corpse" behind in the belief of the mourners.

In Homer there is no fear of the dead. Not because cremation prevails. If there resurface in the epics older religious practices and ideas as Rohde and others note, it is certainly remarkable that fear of the dead does not. Take for instance the much quoted instance of the appearance of the dead Patroclus to Achilles (Il. XXIII $65 \mathrm{ff}$.). The dead go to Hades immediately after death (before the cremation of the body), and there is no return to the world of the living, but Patroclus evidently comes to Achilles (in violation of this law), and this is then a rudiment of the older concept of the "living corpse" ${ }^{62}$. But how is now the fact to be explained that there is no fear here? ${ }^{63}$. Are we to think that the poet manipulates the religious tradition to suit his purposes or that the belief in the "living corpse w was not dominated by fear?

Achilles need not even be reminded of his duties to the dead friend (95 f.), and those duties are certainly not dictated by fear of him. Patroclus, on the other hand, is not frightening or threatening Achilles in any way; he is simply making a request rather impatiently (69 ff.). It just does not seem possible that a warlike people like the Mycenaeans seriously believed in the "living corpse»; they were too intelligent and too ruthless for that. The maltreatment and mutilation of the opponent's body, which are much older than the Mycenaeans themselves, demonstrate that warriors at least are not afraid of the dead ${ }^{64}$.

If people take care of their dead it is not because they fear them. Few, if any, would agree that the Mycenaeans sealed up the

The bat-like creature hovering over the tomb resembles the flittering and fluttering of the Homeric psyche (Vermeule, p. 146); it is a harmless and powerless creature.

${ }^{60}$ Cf. Sakellarakis, Ephem. Archaeol. 1971, p. $188 \mathrm{ff}$.

-1 Cf. B. Rutkowski, *Kykladen und Kreta: Bemerkungen über die Bronzezeitliche Religion*, $A A$ 9, 1976, p. $230 \mathrm{ff}$., who thinks that the journey is protected by the gods and that *der Tote sich auf die Gesegneten Inseln begibt* (p. 239). This would be a suitable place for kings claiming divine descent (cf. p. 239, n. 76 below). If the gods are involved the symbol is not likely to have averting character.

${ }^{62}$ Schnaufer (p. 73 ff.) who on page 75 says characteristically: *Die ganze Szene, in der die Begegnung zwischen der $\psi \cup x \dot{\eta}$ des toten Patroklos und Achill erzählt wird, hat den vorhomerischen Glauben an den lebenden Leichnam zur Voraussetzung".

${ }^{63}$ Not only shows Achilles no sign of fear but he even tries to touch the eliving corpse* and asks that "it * stays a bit longer (p. 69 ff.).

o4 In lliad XXII $358 \mathrm{ff}$. the dying Hector warns Achilles that any maltreatment of his body would bring upon his head the wrath of the gods; he would not have the power to 
tomb entrances to keep the dead shut in and so to protect themselves against them ${ }^{65}$. There is a rational explanation for this sound measure (though not every human action and ordinance need be motivated by reason): blocking of the tomb entrance should discourage thieves from forcing their way in to rob the dead of their precious possessions ${ }^{66}$. Besides, an unsealed tomb would obviously pose a serious health hazard "7.

There is, further, very little, if anything, to suggest that grave offerings were intended to appease the dead and thus to dispose them well towards the living ${ }^{68}$. The dead could claim all or some of their possessions ${ }^{69}$. There must have been a need or desire to honor the dead or some of them by presenting them with gifts at the burial ${ }^{70}$ or afterwards periodically. Other explanations are possible: foreign influence, demonstration of wealth ", etc. On the other hand, "Beigaben" are offered to the dead even after cremation ${ }^{72}$ which is supposed to liberate the living from fear and hence from any need to offer appeasing gifts $^{73}$.

do Achilles any harm. Maybe post-Mycenaean concepts prevail here, but it is hard to imagine a dying man who threatens his opponent with harmful intervention after death, and it is even harder to imagine a merciful opponent on account of such a threat.

-s Cf. Schnaufer, *Durch diese Massnahme wird der Tote im Grab festgehalten. Dí Lebenden schützen sich s) vor seiner Wirksamkeit, da er ihnen schädlich sein könnte* (p. 25). We are told that even in Geometric times is fear of the dead responsible for the heavy masonry of the graves (Schnaufer, p. 46, n. 159). According to Mylonas, Studies, p. 92 and AJA 52, p. 187, the tomb entrance was sealed up in order that the sspirit* be kept *in the grave until the complete decay of the fleshi* since the "spirit* was potentially harmfiul.

ct The Mycenaean tholos tombs were found empty. Were the robbers not afraid of the anger of the dead or did they wait until after decomposition was complete or still after cremation was introduced and the beliefis changed?

"Sibyl, we recall, orders Aeneas (Ameid VI 149 ff.) to bury the dead comrade, for totamque incestat funere classem (v. 150).

on Schnaufer, p. 31 f. Cf. also Mylonas, Studies, p. 92, who speaks of a different kind of placation of the "spirit: : opening the tomb entrance after a new death meant disturbing the espirit" inside, and the "burning of gifts-, along with the fumigation process, served to placate it.

- In Homer Elpenor is happy to have only his weapons and on oar (Od. XI 74 and 77 respectively) while Patroclus does not want anything but the burial rites to take place as soon as possible (II. XXIII $71 \mathrm{ff}$.).

${ }^{70}$ In the Homeric epics the dead are honored (cf. Od. XXIV $65 \mathrm{ff} ., I l$. XXIII $165 \mathrm{ff}$.).

" C.f. Nilsson, GGR I. p. 377.

72 Cf. Andronikos, op. cit., p. 21 ff. and $97 \mathrm{ff}$.

"We are now told that the -Beigaben" have "die Funktion, dem Toten unterwegs und im Hades selbst zur Verfügung ou stehen". But what for? The aliving corpse" is no more. 
Fear of the dead seems, all things considered, not to have been the cause of a cult of the dead. But the view was also advanced that the Mycenaean king enjoyed divine honors during his lifetime which were then continued after his death at his tomb ${ }^{74}$. Mylonas rejected this

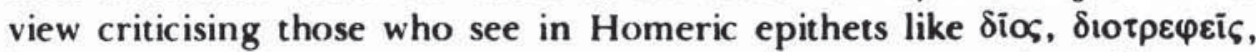
$\delta 10 \gamma \varepsilon v \eta$ s reminiscences of the divine status of Mycenaean kings ${ }^{75}$. But what about the divine descent of King Minos? ${ }^{76}$ In Crete and in other regions of Asia the "priest-kings" were institutionalized ", and we know that the Minoans exerted enormous influence upon the Mycenaeans. Homer speaks of the $\gamma \varepsilon \rho \rho \varsigma \theta \alpha v o ́ v \tau \omega v$ with reference to the burial of distinguished men ${ }^{78}$, and some dead were specially honored in those times ${ }^{79}$, though such honors bestowed upon them do still not prove a cult.

There is something we can learn from the ritual Odysseus performs at the bothros. First of all it serves his purpose which is personal (not religious), and it concerns distinguished dead. If we remove the mythological clothing we find that the ritual, whatever its,specific meaning, was at some time or another in the hands of kings (Odysseus is a king) and, as already stated, concerned dead of high social status (a prophet like Tiresias certainly belongs to them). It is not by chance that pitaltars are located in or near selected tombs ${ }^{80}$.

Cf. Iliad XXII 512 f. and Schnaufer, p. 167, n. 463, who comments on Andromache's words. But she thinks of Hector while still alive; there is nothing here about the needs of the "living corpsen. Similarly II. XXIII 49-5I says nothing to this effect; Achilles simply refers to an old custom without explaining its meaning or even suggesting one.

${ }^{74}$ Webster, op. cit., p. 100

${ }^{75}$ Cf. Mycenae, pp. 176 and 208 ff. Here (p. 178) he abandons the view once held (AJA 52. 1948, p. 78) about the fate of "chosen individuals". In Homer, it may be noted, kings claimed divine ancestry (Desborough, op. cit., p. 242). On the Myccnaean form of $810 \varsigma$ Heubeck, Stud. Mic. 11, 1970, p. $61 \mathrm{ff}$.

${ }^{76}$ On the divine nature of kingship see J. G. Frazer, Lectures on the Early History of Kingship, London 1919, p. 128 ff., S. H. Hooke, Myth, Ritual and Kingship, Oxford 1958, p. 226, Palmer, Interpretations, p. 267, and Ventris-Chadwick, Decipherment, p. 266.

" C.f. Willets, op. cit., p. 83 with bibliography in n. 121.

${ }^{i x}$ Cf. for example IL. XVI 675. Yet even a socially low-rated man like Elpenor now claims his $\gamma \dot{\varepsilon} \rho x(O d$. XI 75 and 77) but the Odyssey is generally agreed to reflect, partly at least, conditions of the poet's own time.

${ }^{79}$ Mylonas, Studies, p. 80, says with reference to the tomb at Drachmani athe person buried in it was treated with greater respect and splendor than usual...*.

${ }^{\text {} 0}$ Mycenaean tholos tombs are provided with floor pits; some are also found in the dromos, and they vary in size as well as in function. Cf. Persson, The Royal Tombs at Dendra, p. 81 ff., Wace, Chamber Tombs at Mycenae, p. 136 ff., Nilsson, op. cit., p. $590 \mathrm{ff}$. On Cretan tomb pits see esp. S. A. Xanthoudides, The Vaulted Tombs of Messara, London 192 : 
If the poetic ritual reflects genuine religious practices as has been argued above and if the interpretation given in this paper is correct there are two conclusions to draw: 1) the ruling class practiced some kind of a cult of the dead, and 2) that the cult served the individual, his family or class. The purpose is of primary significance in determining the nature of the cult, and I would say that the Mycenaeans well understood the advantages of exploiting politically whatever notions there were about the dead in the more remote past of their history. A ruling house that succeeds in impressing upon the rank and file the idea of a living powerful figure, who holds sway over his people even after death and claims his earthly possessions and honors, cannot lose: those bearing the main burden of taxation might be persuaded to be more complaisant, especially in hard times.

To preserve, by means of an impressive ritual, the memory and to extend the influence of a leading figure (long before epic poetry could take over) is, I suggest, a valid reason for organizing and maintaining a cult. If there were any primitive notions about the «living corpse* or genuine religious ideas they could, in a more advanced period of civilization, be manipulated skilfully to serve other purposes ${ }^{81}$.

\section{ODYSSEUS TSAGarakiS}

\footnotetext{
passim. The evidence of fire found nearly everywhere suggests that there tork place purification rites or burnt sacrifices, and the Odyssean passage lends weight to the view of such sacrifices. Whether a cult of the dead would recuire periodic repetition of the rites at the pit altar (cf. Mylonas, Mycenae, p. 178) we do not know; with an altar inside the sealed tomb there would be problems. It is thinkable that facilities could be used outside the tomb or in a more convenient kxation.

"The Romans were hardly innovating in the second century B. C. when they used religion to promote and achieve personal and political ambitions (see $\mathbf{W}$. W. Fowler, The Religious Experience of the Roman People, London 1933. p. 336 ff.).
} 